\title{
Plethora (Novaluron + Indoxacarb) insecticide for the management of tomato fruit borer complex
}

\author{
Abhijit Ghosal $^{1 *}$, Ashim Kumar Dolai ${ }^{2}$ and Monilal Chatterjee ${ }^{3}$ \\ 1،Sasya Shyamala” Krishi Vigyan Kendra, Ramakrishna Mission Vivekananda University, Narendrapur, Kolkata- \\ 700103 (West Bengal), INDIA \\ ${ }^{2}$ Technical officer, AICRP sesame and niger Calcutta University -741252 (West Bengal) INDIA \\ ${ }^{3}$ School of Crop Protection, College of Post Graduate Studies, Central Agricultural University Umiam- 793103 ) \\ (Meghalaya), INDIA \\ *Corresponding author. E-mail: ghosalabhijit87@gmail.com \\ Received: August 26, 2015; Revised received: March 10, 2016; Accepted: May 30, 2016
}

\begin{abstract}
During the past three decades, efforts have been made to reduce the risk of human exposure to pesticides specially insecticides. There is a great demand for safer and more selective insecticides that spare natural enemies and non target organisms. The present investigation was conducted during rabi season 2009 and 2010 , to test the effectiveness of recently developed new ready mix insecticide Plethora (Novaluron $5.25 \%+$ Indoxacarb $4.5 \%$ SC) along with other insecticides against Helicoverpa armigera Hub and Spodoptera litura Fab. infesting tomato. It is observed that Plethora @ $875 \mathrm{ml} /$ ha recorded only 3.75\% fruit damage, while in control plot it was 45.6\%. Though highest cost benefit ratio (1:6.17) was obtained when Plethora was applied at $825 \mathrm{ml} / \mathrm{ha}$. Independently novaluron performed well specially against $S$. litura and indoxacarb showed better performance against $H$. armigera but lamda-cyhalothrin expressed comparatively lower performance than other selected insecticides which received $28.30 \%$ fruit infestation
\end{abstract}

Keywords: Helicoverpa armigera, Indoxacarb, Novaluron, Plethora , Tomato

\section{INTRODUCTION}

Tomato (Lycopersicon esculentum Mill.) is an important vegetable crop throughout the world as well as Indian agriculture as is a good source of vitamins (A and $\mathrm{C}$ ) and minerals. In different parts of West Bengal tomato is cultivated as rabi as well as spring summer crop. About 879.6 thousand hactare of land were under tomato cultivation, producing 18226.6 thousand metric ton fresh fruits in the year 2012-13 in India. Although the total cultivated area and production of tomato in our country have increased gradually over the last few years but the productivity has not increased that much $(20.7 \mathrm{mt} / \mathrm{ha})$ compared to the average of the world yield (33.8 $\mathrm{mt} / \mathrm{ha}$ ) as per FAO, 2014 (Anonymous 2014). Among the factors responsible for low yield of tomato, insect pest attacks are considered to be the most serious ones. Tomato suffers from various insectpests attack starting from nursery to harvest. A major constraint in tomato production during fruiting is Helicoverpa armigera Hubner and Spodoptera litura Fabricus. As tomato is one of the most popular and profitable crop, farmers everywhere feel the need to protect such high value crops from any type of damage caused by insect pests. In world food plant are damaged by more than 10,000 species of insects (Dhaliwal et al., 2007). Sometimes the yield loss by insects reaches as high as $60-70 \%$. Dhaliwal et al. (2010) reported that the Indian agriculture is currently suffering an annual loss of about Rs. 8, 63, 884 million due to insect pests. The present report published by Dhaliwal et al. (2015) showed that currently we are losing about US\$ 36 billion due to insect pests. In spite of various control measures against pests farmers are mainly depend on chemical control which cause consistently increase in crop loss (Dhaliwal and Koul, 2010). The misuse and overuse of pesticides has lead to problems of pesticide resistance, resurgence and contamination of different components of the environment. In spite of a variety of control measures applied against pests, crop losses have consistently shown an increasing trend (Dhaliwal and Koul, 2010). This is due to misuse and overuse of insecticides which cause resistance and increase the survival rate of insect pests. Therefore, toward heavy crop loss, farmers resort to use the pesticides in large quantity, under the adage "if little is good, a lot more will be better" (Aktar et al., 2009). This causes harmful effect on non target living organism (Cork et al., 2003). There is a great demand for safer and more selective insecticides (mostly blue and green labelled) that spare natural enemies and non-target organisms. Consequently new types of insecticides have been developed by agrochemical companies. Although they are mostly synthetic but they are more selective than conventional insecticides. To improve upon this problem, the most 
commonly method for the control of this pest is to have a film of an insecticide over foliage and fruiting bodies (Dotkhile et al. 1992; Sharma et al. 1993). The main objective of the study is to test the effectiveness of a new ready-mixed insecticide- Plethora (novaluron 5.25+ indoxacarb 4.5 SC) developed by Makteshim Agan India Pvt. Ltd. at different concentrations in comparison with novaluron, indoxacarb and lamda-cyhalothrin for controlling the two above mentioned important lepidopteran insect pests' i.e Helicoverpa armigera and Spodoptera litura on tomato.

\section{MATERIALS AND METHODS}

The field experiments were conducted for two consecutive years during rabi (date of transplanting $10^{\text {th }}$ November) season of 2009-10 and 2010 -11. Each insecticide was tested with the recommended dose and the experiment was laid out in randomized block design (RBD) with seven treatments replicated three times at farmar's field (Nadia, West-Bengal). The six insecticides following "good agricultural practices" like three doses of novaluron $5.25 \%+$ indoxacarb $4.5 \%$ $\mathrm{SC}$ at $39.38+33.75,43.31+37.13$ and $45.94+$ $39.38 \mathrm{~g} \mathrm{a.i} / \mathrm{ha}$, novaluron $10 \% \mathrm{EC}$ at $75 \mathrm{~g}$ a.i/ha; indoxacarb $14.5 \% \mathrm{SC}$ at $75 \mathrm{~g}$ a.i/ha and lamda-cyhalothrin $5 \% \mathrm{EC}$ at $15 \mathrm{~g}$ a.i/ha as check (Table 1) along with an untreated control. All other agronomic practices were standard, and initially the crop was protected against sucking pests with acetamiprid @25 g.a.i /ha. Three rounds of chemical treatments were imposed when the target pests coinciding their ETL at 15 days interval with Knapsack sprayer at high volume 500 liters water/ ha with hollow cone nozzle. The control plot was left as such without any plant protection interventions. Ten randomly selected plants were chosen to count the number of $H$. armigera. Spedoptera at one day before and 3 and 10 days after each insecticide application. Tomato cultivar 'Nidhi' was grown in plot of size 20 $\mathrm{m}^{2}$ at spacing of $60 \mathrm{~cm}$ X $50 \mathrm{~cm}$ with recommended package of practices including recommended dose of fertilizer. The rate of infestation of fruits by $H$. armigera was taken into account at each picking.

Statistical analysis: The data were subjected to analysis of variance after making necessary transformation. Per cent mortality is corrected following the Abotts formula (Abbott 1925). Means are differentiated by RBD. Observations were also recorded on yield of the crop.

\section{RESULTS AND DISCUSSION}

There was no significant difference in the preapplication count of larval population between treatments as well as control during rabi season of both the year 2009 and 2010 (Table1). All the treated plots with chemicals were significantly superior in their performance over that of control plots after application of insecticides. At 3 days after spraying, highest percentage (92\%) of reduction of $H$. armigera population was recorded in novaluron $5.25 \%+$ indoxacarb $4.5 \% \mathrm{SC}$ treatments at $875 \mathrm{ml} /$ ha followed by the same chemical at $825 \mathrm{ml} / \mathrm{ha}$ (91.6\%), indoxacarb14.5\% SC $500 \mathrm{ml} / \mathrm{ha}$ (90.5\%), novaluron $10 \% \mathrm{EC}$ at $750 \mathrm{ml} / \mathrm{ha}(75.6 \%)$ and lamdacyhalothrin 5\% EC at $300 \mathrm{ml} / \mathrm{ha}(68.3 \%)$ respectively. After 10 days of spraying, novaluron $5.25 \%+$ indoxacarb $4.5 \% \mathrm{SC}$ at 875 and $825 \mathrm{ml} /$ ha showed highest parcentage of reduction of $H$. armigera population (100\%), while standard check lamda-cyhalothrin recorded decreased per cent reduction of $H$. armigera population $(60.5 \%)$. A steady increase in the $H$. armigera population was observed in untreated control plot throughout the experimental period.

As revealed in Table 2, pre-application count of Spodoptera larval population was not varied significantly from each other and control during rabi 2009- 2011. After 10 days of spraying, highest reduction of Spodoptera larval population was recorded in novaluron

Table 1. Effect of different treatment schedules of Plethora (Novaluron 5.25\%+Indoxacarb $4.5 \% \mathrm{SC}$ ) against Helicoverpa armigera on tomato (Mean of two seasons).

\begin{tabular}{|c|c|c|c|c|c|}
\hline \multirow[t]{2}{*}{ Treatments } & \multirow[t]{2}{*}{$\begin{array}{l}\text { Dose } \\
\text { (gm a.i. /ha) }\end{array}$} & \multirow{2}{*}{$\begin{array}{l}\text { Spray } \\
\text { dosage } \\
\text { (ml/ha) }\end{array}$} & \multirow{2}{*}{$\begin{array}{l}\text { Mean No. of Heli- } \\
\text { coverpa } \\
\text { larvae /ten plants } \\
\text { before spray }\end{array}$} & \multicolumn{2}{|c|}{$\begin{array}{l}\text { Mean \% reduction/ increase }(+) \text { in larval } \\
\text { population at different intervals (days) } \\
\text { after spray }\end{array}$} \\
\hline & & & & & $10^{\mathrm{th}}$ \\
\hline Novaluron $5.25 \%+$ & (39.38+ & 750 & 12.50 & $78.4(62.31)$ & $81.5(64.53)$ \\
\hline Indoxacarb4.5\%SC & $33.75)$ & & & & \\
\hline Novaluron $5.25 \%+$ & $(43.31+$ & 825 & 11.75 & $91.6(73.15)$ & $100(90.00)$ \\
\hline Indoxacarb4.5\%SC & 37.13) & 020 & (1.1. & & \\
\hline Novaluron $5.25 \%+$ & $(45.94+$ & 875 & 12.25 & $92.0(73.57)$ & $100(90.00)$ \\
\hline Indoxacarb4.5\% $\mathrm{SC}$ & 39.38) & (נ) & & & \\
\hline Novaluron $10 \% \mathrm{EC}$ & 75 & 750 & 12.00 & $75.6(60.40)$ & $78.7(62.51)$ \\
\hline Indoxacarb $14.5 \% \mathrm{SC}$ & 75 & 500 & 11.75 & $90.5(72.05)$ & $85.5(67.62)$ \\
\hline $\begin{array}{l}\text { Lamda-Cyhalothrin } \\
5 \% \mathrm{EC}\end{array}$ & 15 & 300 & 11.00 & $68.3(55.73)$ & $\begin{array}{l}60.5 \\
(51.06)\end{array}$ \\
\hline Control (Untreated) & - & - & 11.75 & $+42.5(0.00)$ & $\begin{array}{l}+58.0 \\
(0.00)\end{array}$ \\
\hline $\mathrm{CD}$ at $5 \%$ & - & - & N.S & 4.97 & 7.64 \\
\hline
\end{tabular}

Figures in parentheses are angular transformed values.

N.S.: Not significant. 
Table 2. Effect of different treatment schedules of Plethora (Novaluron 5.25\%+Indoxacarb 4.5\%SC) against Spodoptera litura on tomato (Mean of two seasons).

\begin{tabular}{|c|c|c|c|c|c|}
\hline \multirow[t]{2}{*}{ Treatments } & \multirow[t]{2}{*}{$\begin{array}{l}\text { Dose } \\
\text { (gm a.i. /ha) }\end{array}$} & \multirow[t]{2}{*}{$\begin{array}{l}\text { Spray } \\
\text { dosage } \\
(\mathrm{ml} / \mathrm{ha})\end{array}$} & \multirow{2}{*}{$\begin{array}{l}\text { Mean No. of } \\
\text { Spodoptera } \\
\text { larvae /ten } \\
\text { plants before } \\
\text { spray }\end{array}$} & \multicolumn{2}{|c|}{$\begin{array}{l}\text { Mean \% reduction/increase } \\
(+) \text { in larval population at } \\
\text { different intervals (days) } \\
\text { after spray }\end{array}$} \\
\hline & & & & $3^{\text {rd }}$ & $10^{\text {th }}$ \\
\hline $\begin{array}{l}\text { Novaluron } 5.25 \%+\text { Indox- } \\
\text { acarb4.5\%SC }\end{array}$ & $(39.38+33.75)$ & 750 & 4.50 & $76.2(60.80)$ & $91.6(73.15)$ \\
\hline $\begin{array}{l}\text { Novaluron } 5.25 \%+\text { Indox- } \\
\text { acarb4.5\%SC }\end{array}$ & $(43.31+37.13)$ & 825 & 5.00 & $89.0(70.63)$ & $100(90.00)$ \\
\hline $\begin{array}{l}\text { Novaluron } 5.25 \%+\text { Indox- } \\
\text { acarb } 4.5 \% \mathrm{SC}\end{array}$ & $(45.94+39.38)$ & 875 & 4.75 & $91.0(72.54)$ & $100(90.00)$ \\
\hline Novaluron $10 \% \mathrm{EC}$ & 75 & 750 & 5.00 & $73.4(58.95)$ & $97.0(80.03)$ \\
\hline Indoxacarb $14.5 \% \mathrm{SC}$ & 75 & 500 & 4.50 & $81.5(64.53)$ & $62.0(51.94)$ \\
\hline $\begin{array}{l}\text { Lamda-Cyhalothrin 5\% } \\
\text { EC }\end{array}$ & 15 & 300 & 5.25 & $62.6(52.30)$ & $11.5(19.82)$ \\
\hline Control (Untreated) & - & - & 4.75 & $+25.8(0.00)$ & $+34.3(0.00)$ \\
\hline $\mathrm{CD}$ at $5 \%$ & - & - & N.S & 4.97 & 9.12 \\
\hline
\end{tabular}

Figures in parentheses are angular transformed values. N.S.: Not significant.

Table 3. Effect of different treatment schedules of Plethora (Novaluron 5.25\%+Indoxacarb $4.5 \% \mathrm{SC}$ ) on tomato crop yield with cost benefit ratio. (Mean of three sprays).

\begin{tabular}{lllllc}
\hline Treatments & $\begin{array}{l}\text { Dose } \\
\text { (gm a.i. } / \text { ha) }\end{array}$ & $\begin{array}{l}\text { Spray } \\
\text { dosage } \\
\text { (ml/ha) }\end{array}$ & $\begin{array}{l}\text { Mean \% of } \\
\text { fruit damage }\end{array}$ & $\begin{array}{l}\text { Fruit Yield with- } \\
\text { out infestation } \\
\text { (q/ha) }\end{array}$ & $\begin{array}{l}\text { Cost: } \\
\text { Benefit } \\
\text { ratio }\end{array}$ \\
\hline Novaluron 5.25\%+ Indoxacarb4.5\%SC & $(39.38+33.75)$ & 750 & $9.5(17.95)$ & 138.5 & $1: 5.33$ \\
Novaluron 5.25\%+ Indoxacarb4.5\%SC & $(43.31+37.13)$ & 825 & $4.25(11.83)$ & 152.6 & $1: 6.17$ \\
Novaluron 5.25\%+ Indoxacarb4.5\%SC & $(45.94+39.38)$ & 875 & $3.75(11.09)$ & 154.4 & $1: 6.07$ \\
Novaluron 10\%EC & 75 & 750 & $6.60(14.89)$ & 137.6 & $1: 3.63$ \\
Indoxacarb 14.5\%SC & 75 & 500 & $7.50(16.00)$ & 141.0 & $1: 5.30$ \\
Lamda-Cyhalothrin 5\%EC & 15 & 300 & $28.30(32.14)$ & 93.2 & $1: 3.06$ \\
Control (Untreated) & - & - & $45.6(42.13)$ & 78.5 & - \\
CD at 5\% & - & - & 9.67 & 14.63 & - \\
\hline
\end{tabular}

Figures in parentheses are angular transformed values.

$5.25 \%+$ indoxacarb $4.5 \% \mathrm{SC}$ treatments at 875 and $825 \mathrm{ml} / \mathrm{ha}(100 \%)$ followed by novaluron at $750 \mathrm{ml} / \mathrm{ha}$ (97\%), as compare to other treatments including control. Lamda cyhalothrin recorded lowest percentage of reduction of borer population (11.5\%) after 10 days of spraying. A perusal of data in Table 3 showed that percentage of fruit infested by $H$. armigera was lowest in novaluron $5.25 \%+$ indoxacarb $4.5 \%$ SC treatments at 875 and $825 \mathrm{ml} / \mathrm{ha}(3.75-4.25 \%)$ also highest yield and cost benefit ratio than the other treatments as compared to untreated control (45.6\% infestation). The overall performance including favourable benefit cost ratio was noted when Plethora (novaluron $5.25+$ indoxacarb $4.5 \mathrm{SC}$ ) applied at $825 \mathrm{ml} / \mathrm{ha}$ This new ready mixed insecticide reduced the population of Helicoverpa armigera up to $100 \%$ within three days after third application initially and reduced the population of Spodoptera litura within ten days after first application that led to increases in yield. Novaluron performed well specially against Spodoptera litura and indoxacarb showed better performance against Helicoverpa armigera but lamda-cyhalothrin expressed comparatively lower efficacy than other insecticides.
During the present study the insecticide Plethora showed quick knock down effect and longer persistence on the treated surface can safely be used in controlling the fruit borer infesting tomato. Plethora is highly vulnerable to lepidopteran insect pest with two novel modes of action viz. chitin biosynthesis inhibition creates abortive moulting by novaluron and blockage of axonal sodium channel causing rapid cessation of feeding and paralysis by indoxacarb. Yogeeswarudu and Venkata Krishna (2014) in their findings concluded that novel insecticides indoxacarb and novaluron can manage Helicoverpa up to 95.83 per cent and 87.12 per cent respectively. Gamil et al. (2011) concluded that $2^{\text {nd }}$ instar larvae of Spodoptera littoralis are more susceptible to indoxacarb than $4^{\text {th }}$ instar. Moadeli et al. (2014) evaluated the $\mathrm{LC}_{50}$ and $\mathrm{LC}_{90}$ values of indoxacarb againt Spodoptera exigua which were 2.510 and $38.828 \mathrm{mg}$ a.i. /1 respectively. Mishra (1986); Singh and Singh (1990); Bhatt and Patel (2002) also reported similar result about the effect of these novel insecticides on $H$. armigera and $S$. litura. In connotation of their findings our present report can be judged because plethora is the combination product 
of both novaluron and indoxacarb and their pre mix may pronounce synergist effect over their individual effect, which is also reflected in our studies also. The report of the present author can be justified with the findings of Das et al. (2015), who reported that mixed formulation of novaluron 5.25+indoxacarb 4.5 SC recorded the most effective insecticides than that of their sole formulation against Helicoverpa armigera. Novel insecticides like indoxacarb being target specific to lepidopteran pest could not affect the natural enemies (Kambrekar et al., 2012). Both novaluron and indoxacarb are safe to non target organisms and quickly degraded to non toxic products so it can be assumed that their pre mix formulated product Plethora (novaluron 5.25+indoxacarb $4.5 \mathrm{SC}$ ) also would be safe towards the non targets.

\section{Conclusion}

Plethora (Novaluron $5.25 \%+$ Indoxacarb 4.5\% SC) @ $875 \mathrm{ml} /$ ha recorded only $3.75 \%$ fruit damage caused by fruit borer complex (H. armigera \& $S$. litura), while in control plot it was $45.6 \%$. Simultaneously highest marketable fruit yield (154.4 q/ha) was obtained from novaluron $5.25 \%+$ indoxacarb 4.5\% SC @ $875 \mathrm{ml} / \mathrm{ha}$. Though highest cost benefit ratio $(1: 6.17)$ was obtained when Plethora was applied at $825 \mathrm{ml} / \mathrm{ha}$. Independently novaluron performed well specially against $S$. litura and indoxacarb showed better performance against $H$. armigera but lamda-cyhalothrin expressed comparatively lower performance than other selected insecticides which recorded $28.30 \%$ fruit infestation. We can conclude that the technical formulation of novaluron 5.25\%+ indoxacarb 4.5\% SC (Plethora) @ 875 $\mathrm{ml} /$ ha can protect the tomato crop infesting with fruit borer complex (Helicoverpa and Spodoptera) more efficiently than that of their sole use. From our present result we confirm that novaluron $5.25 \%+$ indoxacarb $4.5 \%$ SC@825 ml/ha can effectively manage the crop with higher cost benefit ratio.

\section{ACKNOWLEDGEMENTS}

Authors are highly thankful to Makteshim Agan India Pvt. Ltd. for their support and cooperation and Department of Agricultural Entomology, Bidhan Chandra Krishi Viswa Vidyalaya, Nandia (WB) for giving opportunities for research.

\section{REFERENCES}

Abbott, W.S. (1925). A method of computing the effectiveness of an insecticide. J. Econ. Entomol., 18: 265-267.

Aktar, M.W. Sengupta, D. and Chowdhury, A. (2009). Impact of pesticide use in Indian agriculture - Their benefits and hazards. Interdisciplinary Toxicology, 2 (1):112 .

Anonymous (2014). Indian Horticulture Database. National
Horticulture Board, Tomato, Ministry of Agriculture, Govt. of India, pp.181-257.

Bhatt, N.J. and Patel, R.K. (2002). Bioefficacy of various insecticides against Helicoverpa armigera on chickpea. Indian J. Entomol., 64: 27-34.

Cork, A. Kamal, N.Q. Alam, S.N. Choudhury, J.C.S. and Talekar, N.S. (2003). Pheromone and their applications to insect pest control. Bangladesh J. Entomol., 13:1-13.

Das B.C. Patra S. Dhote V.W. Alam SK.F. Chatterjee M.L. and Samanta A. (2015). Mix formulations: An alternative option for management of gram pod borer, Helicoverpa armigera $\mathrm{H}$. and pod fly, Melanagromyza obtusa M. in pigeon pea. Legume Res., 38 (3): 396-401.

Dhaliwal, G.S. Jindal, V. and Bharathi, M. (2015). Insect Pest Problems and Crop Losses: Changing Trends. Indian J. Entomol., 77 (2): 165-168.

Dhaliwal, G.S. Jindal, V. and Dhawan, A.K. (2010). Insect Pest Problems and Crop Losses: Changing Trends. Indian J. Ecol., 37 (1): 1-7.

Dhaliwal, G.S. Dhawan, A.K. and Singh, R. (2007). Biodiversity and ecological agriculture: Issues and perspectives. Indian J. Ecol., 34 (2): 100-109.

Dhaliwal, G.S. and Koul, O. (2010). Quest for Pest Management:From Green Revolution to Gene Revolution. Kalyani Publishers, New Delhi.

Datkhile, R.V. Pawar, S.A. Mote U.N. and Khaive, V.M. (1992). Bioefficacy of different insecticides against gram pod borer Heliothis armigera on chickpea, Cicer arietinum L. Bioecology and control of insect pests. Proc. National Sym. Growth, (NSG'92), Devt. Cntl. Technol. Insect Pests, pp: 156-160.

Gamil, W.E. Mariyb, F.M. Youssefb, L.A. Abdel Halima, S.M. (2011). Effect of Indoxacarb on some biological and biochemical aspects of Spodoptera littoralis (Boisd.) larvae. Ann. Agril. Sci., 56 (2): 121-126.

Kambrekar, D.N. Somanagouda, G. Basavarajappa, M.P. and Halagalimath, S.P. (2012). Effect of different dosages of emamectin benzoate $5 \mathrm{SG}$ and indoxacarb 14.5 SC on pod borer, Helicoverpa armigera infesting chickpea. Legume Res., 35 (1): 13-17.

Mishra, P.N. (1986). Studies on the bio-efficacy of some insecticides against the pest complex oftomato, $L y$ copersicon esculentus Mill., var. Pusa Ruby. Madras Agric. J. 71: 673-676.

Moadeli, T. Hejazi, M.J. and Golmohammadi, Gh. (2014). Lethal Effects of Pyriproxyfen, Spinosad, and Indoxacarb and Sublethal Effects of Pyriproxyfen on the $1^{\text {st }}$ Instars Larvae of Beet Armyworm, Spodoptera exigua Hubner (Lepidoptera: Noctuidae) in the Laboratory. $J$. Agr. Sci. Tech., 16: 1217-1227.

Sharma, S.P. Saini, M.L. and Goel, S.C. (1993). Effect of synthetic pyrethroids on gram Cicer arietinum (L.) and correlation studies. Bioecology and control of insect pests. Proceedings of the National Symposium on Growth, Development and Control Technology of Insect Pests, (GDCTIP'93), Tamil Nadu, pp: 184-187.

Singh, D. and Singh, D.D. (1990). Control of tomato fruit borer, Heliothis armigera Hubner with Synthetic pyrethroids. Indian J. Entomol., 52: 534-540.

Yogeeswarudu, B and Venkata Krishna, K. (2014). Field studies on efficacy of novel insecticides against Helicoverpa armigera (Hubner) infesting on Chickpea. J. Entomol. Zool. Stud., 2 (4): 286-289. 